\title{
ADDITIONS TO THE PLEUROCARPOUS MOSSES OF BANGLADESH : FAMILY - PLAGIOTHECIACEAE
}

\author{
HAMida Khatun ${ }^{1}$ and Syed HadiUZzaman \\ Department of Botany, University of Dhaka, Dhaka 1000, Bangladesh
}

Key words: Pleurocarpous mosses, Hypnobryales, Plagiotheciaceae, Bangladesh

In a previous publication, three species of the genus Stereophyllum, namely $S$. tavoyense, S. anceps and S. ligulatum were reported (Khatun and Hadiuzzaman 1994). In this paper detailed account of two newly recorded species of Stereophyllum, namely $S$. decorum and S. wightii have been presented. These two species are epiphytic on different trees and are usually abundant during rainy season. The present study also revealed that the genus Stereophyllum of the family Plagiotheciaceae under the order Hypnobryales is fairly common and widespread in Bangladesh. The studied specimens are preserved in Dhaka University Herbarium.

1. Stereophyllum decorum (Mitt.) Wijk. \& Marg. in Taxon 9: 52 (1960)

(Plate 1)

S. chionostomoides Broth. in Dix., J. Bot. 63: 11(1925) nom.nud. in synom.

Leskea longirostris Schwaegr. in Sp. Musc. Suppl. 3(2): 290A (1830) hom. illeg.

Hypnum decorum Mitt. in Musc. Ind. Or. : 77 (1859)

Small to medium-sized, green, glossy, caespitose plants. Main stem creeping, irregular branches. Leaves very dense, homomallous, erectopatent, shrunk but erectopatent to spreading when dry, ovate, lanceolate, concave, tip narrowly acute, c. $3 \times$ $1 \mathrm{~mm}$, margin smooth throughout the leaf. Costa strong, single, covering two-third of the leaf. Leaf cells linear, c. $90 \times 10 \mu \mathrm{m}$ at apex, broader and shorter near base, extreme basal and alar cells quadrate c. $25 \times 25 \mu \mathrm{m}$, lattice-like at alar. Sporophyte usually on main stem. Seta erect, 1 to $2 \mathrm{~cm}$ long. Capsule constricted under mouth when dry. Peristome normal, double, basal membrane high, exostome and endostome in same height.

Specimens examined: This species is widely distributed all over the country. However, populations were found in abundance in the following localities. Jamalpur: Islampur, on bark of tree, Md. Fazle Rabbi, 15.06.1989, 40; Noakhali: Sreenarayanpur, on bark of tree, Lutfa Rahman, 12.05.1975, 117; Pabna: Paksey, on bark of tree, Prodip Kundu, 13.07.1998, 1275; Panchagarh: Telipara, on bark of tree, Hamida Khatun, Md. Yousuf Ali, Monnuzan Begum, Mahbuba Sultana and Sohel Chowdhury, 23.12.1998, 1342; Tangail: Modhupur Forest, on bark of tree, Farida Rahman, 12.06.1996, 684.

\footnotetext{
${ }^{1}$ Corresponding author. E-mail: hamida_92@yahoo.com
} 
Note: Leaves dense, homomallous or bent to one side, erectopatent, ovate-lanceolate, concave, leaf tip narrowly acute and lattice-like at alar are the important features of this species.

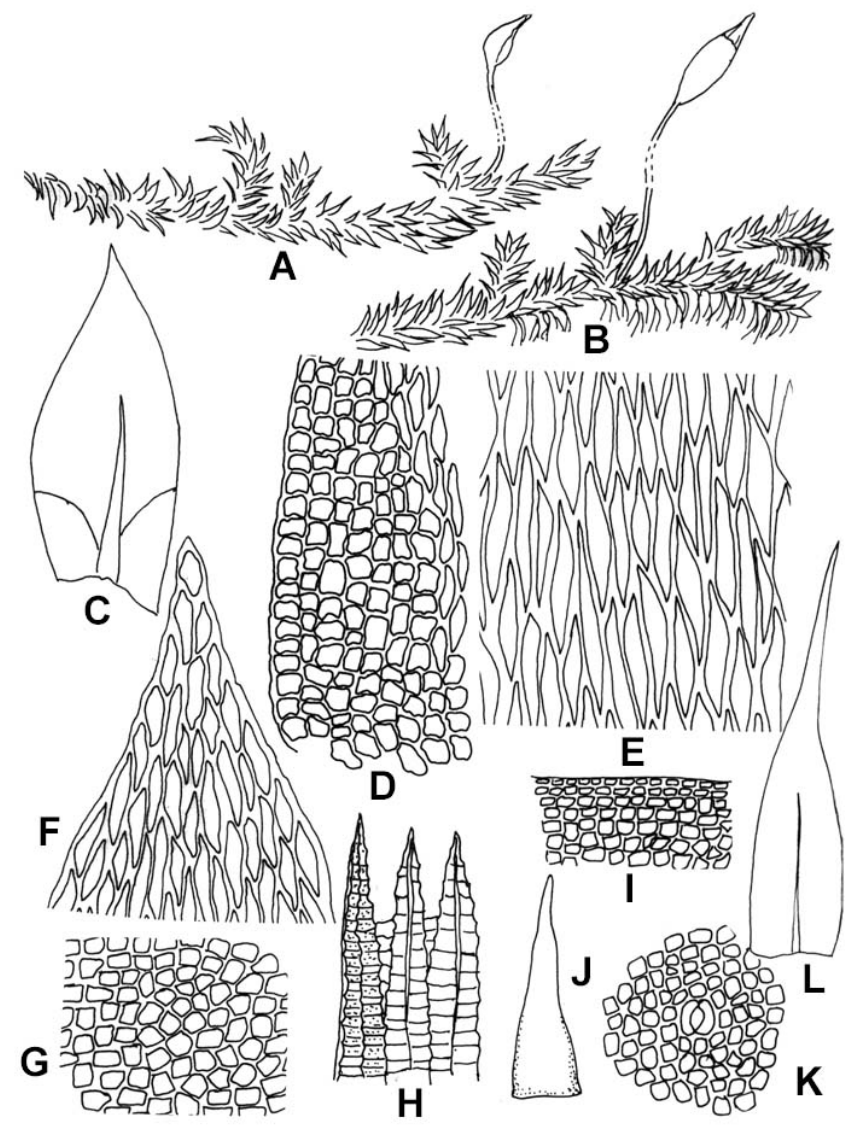

Plate 1. Stereophyllum decorum. A. Dry plant $(\times 5)$, B. Wet plant $(\times 5)$, C. Leaf $(\times 18)$, D. Basal laminal cells $(\times 135)$, E. Middle laminal cell $(\times 135)$, F. Apical laminal cells $(\times 135)$, G. Exothecial cells of the capsule $(\times 60)$, H. Peristome teeth $(\times 100)$, I. Mouth cells of capsule $(\times 60)$, J. Operculum $(\times 18)$. K. Exothecial cell with stomata $(\times 60)$, L. Perichaetial leaf $(\times 18)$.

2. Stereophyllum wightii (Mitt.) Jaeg. in Ber. S. Gall. Naturw. Ges. 1877-78: 279 (1880)

(Plate 2)

Hypnum wightii Mitt. in Musci Ind, Or. : 82 (1859)

Plant slender to rather large, main stem creeping, moderately robust, shiny and silky, flat, light to dark green, sometimes yellow-green mats, radiculose on the lower side, mostly corticolous, irregularly branched, branches horizontal, blunt. Leaves crowded, somewhat complanate, about 4 lateral rows better developed, oblong-lanceolate, apex acute, acuteness of the leaf tip is variable, sometimes revolute at both margins, very often 
asymmetrical with a stout single costa extending two-third to three-fourth the length of the leaf, concave, erectopatent, lower leaves on branches sometimes spreading, appressed to stem when dry, margin often inflexed on one side at base, margin entire, except for a few faint teeth at the apex, c. $1.6 \times 0.5 \mathrm{~mm}$, narrowed at leaf base, sometimes broad. Leaf cells elongated, elliptical-rhomboid, c. $56.7 \times 7.2 \mu \mathrm{m}$ at middle, c. $51 \times 10 \mu \mathrm{m}$ at top, basal cells slightly wider, a large area of rounded quadrate to rectangular cells extending



Plate 2. Stereophyllum wightii. A. Dry plant $(\times 5)$, B. Wet plant $(\times 5)$, C-E. Leaves $(\times 18)$, F. Basal laminal cells $(\times 150)$, G. Middle laminal cells $(\times 150)$, H. Apical laminal cells $(\times 150)$, I. Perichaetial leaf $(\times 18)$, J. Peristome teeth $(\times 100), \mathrm{K}$. Mouth cells of capsule $(\times 150)$, L. Exothecial cells of capsule $(\times 150)$.

almost to the costa at the insertion, on both side of the costa, number of alar cells are not equal, one side is less than the other side and they are laxly arranged, c. $18.15 \times 15.67$ $\mu \mathrm{m}$. Sporophyte on main stem, sometimes on branch stem. Perichaetial leaves erect, 0.1 to $1.5 \mathrm{~mm}$ long, costate, narrowed at top, wide at base. Seta slender, long, reddish-brown, smooth, 10 to $12 \mathrm{~mm}$ long. Capsule erect, sometimes horizontal or nearly so, more or less cylindric, 1 to $2 \mathrm{~mm}$ long and $0.5 \mathrm{~mm}$ in diameter. Peristome normal, double, exostome 
longer than endostome and c. $200 \mu \mathrm{m}$ high, basal membrane more or less high. Spores round, greenish in colour, 10 to $15 \mu \mathrm{m}$ in diameter.

Specimens examined: This species is widely distributed all over the country. However, a number of good populations were found in the following localities. Dhaka: Mirpur, on bark of tree, Bijon Kumar Bhowmik, 10.02.1996, 976; Gazipur: Konabari, on bark of tree, Hamida Khatun, 18.04.1994, 1082; Moulvi Bazar: Srimangal, on bark of tree, Syeda Humaira Afroze, Md. Shamim, Md. Shahabuddin, 03.03.1992, 270; Narsingdi: Raipura, on the of tree, Hamida Khatun, 18.04.1991, 1085; Panchagarh: Tetulia, by the bank of River Mohananda, on bark of tree, Hamida Khatun, 23.12.1998, 1212.

Note: The distinguishing features of this species are: leaf asymmetrically oblonglanceolate, apex acute, tip narrower than other species of the same genus, leaf margin often inflexed on one side at base and alar covers the whole of leaf base.

\section{Reference}

Khatun, H. and Hadiuzzaman, S. 1994. Taxonomic studies of some pleurocarpic mosses of Bangladesh. Bangladesh J. Bot. 23 (1): 113-122. 